\title{
Analisis Pemahaman Konsep Vektor pada Siswa SMA Negeri 5 Palu
}

\author{
Yuwarti, Marungkil Pasaribu, dan Amiruddin Hatibe \\ Yuwarti.physics12@gmail.com \\ Program Studi Pendidikan Fisika FKIP Universitas Tadulako \\ Jl. Soekarno Hatta Km. 9 Kampus Bumi Tadulako Tondo Palu - Sulawesi Tengah
}

\begin{abstract}
Abstrak - Penelitian ini bertujuan untuk menganalisis pemahaman konsep vektor pada siswa SMA Negeri 5 Palu. Responden penelitian terdiri dari 6 orang siswa kelas XII MIPA1. Data diperoleh melalui tes pemahaman konsep vektor berupa soal esai yang berjumlah 9 butir soal. Soal disusun berdasarkan 3 kategori pemahaman yaitu menerjemahkan yang diwakili oleh soal nomor 1, 2 dan 3, menafsirkan yang diwakili oleh soal nomor 4, 5, dan 6 serta mengekstrapolasi yang diwakili oleh soal nomor 7, 8 dan 9. Data penelitian dianalisis menggunakan pendekatan deskriptif-kualitatif dengan merujuk jawaban yang diberikan responden dalam mengerjakan tes pemahaman konsep vektor dan juga berdasarkan hasil wawancara antara peneliti dengan responden. Hasil penelitian menunjukkan bahwa pemahaman konsep vektor siswa masih tergolong rendah. Siswa sudah dapat memahami dengan baik konsep vektor pada kategori menerjemahkan dan menafsirkan, akan tetapi dalam hal mengekstrapolasi kemampuan siswa masih sangat kurang. Untuk mengatasi rendahnya pemahaman vektor siswa, perlu perhatian dari pendidik serta dilakukan remediasi mengenai konsep vektor, khususnya vektor kinematika karena akan mempengaruhi pemahaman siswa pada jenjang berikutnya.
\end{abstract}

Kata Kunci: Pemahaman Konsep, Vektor.

\section{PENDAHULUAN}

Kurikulum merupakan suatu rencana yang memberi pedoman atau pegangan dalam proses kegiatan belajar mengajar guna untuk mencapai tujuan-tujuan pendidikan yang diinginkan oleh sekolah yang dianggap cukup tepat dan penting untuk dicapai ${ }^{[1]}$.

Tujuan pembelajaran fisika pada hakikatnya adalah untuk mengantarkan pemahaman siswa menguasai konsep-konsep dan keterkaitannya untuk dapat memecahkan masalah terkait dalam kehidupan sehari-hari. Menguasai memiliki arti bahwa pembelajaran fisika harus menjadikan siswa tidak sekadar tahu (knowing) dan hafal (memorizing) tentang konsep-konsep, melainkan harus menjadikan siswa mengerti dan memahami (to understand) konsep-konsep tersebut dan menghubungkan keterkaitan suatu konsep dengan konsep lain [2].

Untuk mencapai tujuan tersebut, maka diperlukan kemampuan siswa yang baik dalam menguasai konsep pada mata pelajaran fisika. Konsep merupakan pemikiran seseorang terhadap suatu realita. Baik peserta didik maupun tenaga pendidik dapat mengalami kesulitan dalam menyelesaikan permasalahanpermasalahan fisika. Hal ini dikarenakan mereka kurang atau tidak menguasai konsep-konsep fisika, atau bahkan mengalami kesalahan dalam pemahaman konsep fisika tersebut. Salah satu materi yang harus dikuasai siswa dengan baik adalah vektor. Vektor merupakan suatu konsep yang berkaitan erat dengan materi lain pada fisika, seperti gerak, gaya, momentum, impuls, momen gaya, usaha, listrik, magnet, dan lainlain. Vektor banyak digunakan dalam melakukan penyelesaian masalah dalam fisika.

Masih banyak siswa yang mengalami kesulitan dalam memahami materi vektor. Dari 6 kelas, nilai tertinggi yang diperoleh siswa pada saat tes besaran vektor adalah 69 [3]. Mahasiswa mengalami kesulitan memahami konsep vektor gaya dalam Hukum Newton yang meliputi kesulitan memahami konsep simbol matematis dan dalam memahami proyeksi vektor. Dari enam mahasiswa yang dijadikan responden, hanya satu mahasiswa yang menjawab pertanyaan tentang vektor dengan benar ${ }^{[4]}$. Mahasiswa yang telah menyelesaikan mata kuliah fisika dasar masih memiliki miskonsepsi dalam menguraikan komponen vektor dan kesulitan dalam perhitungan matematis dari perkalian silang dan perkalian titik suatu vektor [5]. Mahasiswa yang telah menyelesaikan mata kuliah mekanika mengalami kesulitan serius terhadap sketsa vektor satuan dalam arah vektor pada bidang koordinat Cartesius ${ }^{[6]}$. Selain itu, juga masih terdapat mahasiswa yang mengalami kesulitan dalam menjumlah dan mengurangkan vektor meskipun soal yang diberikan disertai dengan representasi panah [7].

Berdasarkan hasil penelitian-penelitian tersebut dapat diketahui bahwa masih terdapat banyak permasalahan yang dihadapi siswa dan mahasiswa dalam memahami konsep vektor. 
Mahasiswa mengalami kesulitan dalam memahami dan menerapkan konsep vektor disebabkan karena pemahaman dasar tentang vektor yang dimilikinya ketika SMA masih kurang atau rendah. Sehingga peneliti tertarik untuk melakukan penelitian tentang pemahaman konsep vektor pada siswa disalah satu SMA Negeri di kota Palu.

\section{METODOLOGI PENELITIAN}

Penelitian ini merupakan penelitian deskriptif kualitatif yaitu penelitian yang dilakukan dengan tujuan utama untuk memberikan gambaran atau deskripsi tentang suatu keadaan secara objektif sesuai dengan faktafakta yang ada. Subjek pada penelitian ini adalah siswa kelas XII MIPA1 SMAN 5 Palu. Responden penelitian ini berjumlah 6 orang yang dipilih berdasarkan kategori tinggi, sedang dan rendah. Responden tersebut diberikan tes pemahaman konsep vektor kinematika yang berupa soal esai dan mengikuti wawancara untuk menelusuri pemahaman tentang vektor secara mendalam. Enam orang responden tersebut diperoleh dari hasil tes awal yang diberikan yaitu berupa tes pilihan ganda dan dengan menghitung letak kuartil nilai siswa menggunakan persamaan $1^{[8]}$.

$$
K_{i}=\frac{i(n+1)}{4}
$$

\section{HASIL DAN PEMBAHASAN}

Hasil yang diperoleh dari pemberian tes pilihan ganda kepada seluruh siswa kelas XII MIPA1 dapat disajikan dalam tabel 4.1.

TABEL 1. DISTRIBUSI JAWABAN SISWA BERDASARKAN TES PILIHAN GANDA

\begin{tabular}{cccc}
\hline \multirow{2}{*}{ Kategori Soal } & \multirow{2}{*}{$\begin{array}{c}\text { Nomor } \\
\text { Soal }\end{array}$} & \multicolumn{2}{c}{$\begin{array}{c}\text { Jumlah siswa } \\
\text { menjawab }\end{array}$} \\
\cline { 3 - 4 } & & Benar & Salah \\
\hline \multirow{3}{*}{ Menerjemahkan } & 1 & 28 & 0 \\
& 2 & 28 & 0 \\
Menafsirkan & 3 & 24 & 4 \\
\hline \multirow{3}{*}{ Mengekstrapolasi } & 4 & 26 & 2 \\
& 5 & 25 & 3 \\
& 6 & 28 & 0 \\
\hline & 7 & 18 & 10 \\
& 9 & 24 & 4 \\
\hline
\end{tabular}

Hasil yang diperoleh dari pemberian tes esai kepada enam orang responden yang termasuk dalam kategori tinggi, sedang dan rendah dapat disajikan dalam tabel 4.2.
p-ISSN 2338-3240, e-ISSN 2580-5924

TABEL 2. DISTRIBUSI JAWABAN RESPONDEN BERDASARKAN TES ESAI.

\begin{tabular}{|c|c|c|c|c|c|}
\hline \multirow{3}{*}{$\begin{array}{c}\text { Kategori } \\
\text { Soal }\end{array}$} & \multirow[t]{3}{*}{ No. } & \multicolumn{4}{|c|}{ Responden } \\
\hline & & \multicolumn{2}{|c|}{ Menjawab Benar } & \multicolumn{2}{|c|}{ Menjawab Salah } \\
\hline & & Kategori & Kode & Kategori & Kode \\
\hline \multirow[t]{7}{*}{$\begin{array}{l}\text { Menerje- } \\
\text { mahkan }\end{array}$} & 1 & Tinggi & $\begin{array}{l}\mathrm{R}-01, \\
\mathrm{R}-02\end{array}$ & Sedang & $\begin{array}{c}\text { R-03, } \\
R-04\end{array}$ \\
\hline & & Rendah & $\mathrm{R}-06$ & Rendah & $\mathrm{R}-05$ \\
\hline & 2 & Tinggi & $\begin{array}{l}\mathrm{R}-01 \\
\mathrm{R}-02\end{array}$ & & \\
\hline & & Sedang & $\begin{array}{l}\mathrm{R}-03 \\
\mathrm{R}-04\end{array}$ & & \\
\hline & & Rendah & $\begin{array}{l}\text { R-05, } \\
\text { R-06 }\end{array}$ & & \\
\hline & 3 & Tinggi & $\begin{array}{l}\mathrm{R}-01 \\
\mathrm{R}-02\end{array}$ & Sedang & $\begin{array}{l}\text { R-03, } \\
\text { R-04 }\end{array}$ \\
\hline & & Rendah & $\mathrm{R}-05$ & Rendah & $\mathrm{R}-06$ \\
\hline \multirow{8}{*}{$\begin{array}{c}\text { Menafsir- } \\
\text { kan }\end{array}$} & 4 & Tinggi & $\mathrm{R}-01$ & Sedang & $\mathrm{R}-04$ \\
\hline & & Sedang & $\begin{array}{l}R-02 \\
R-03\end{array}$ & Rendah & $\mathrm{R}-06$ \\
\hline & & Rendah & $\mathrm{R}-05$ & & \\
\hline & 5 & Tinggi & $\begin{array}{l}\text { R-01, } \\
\text { R-02 }\end{array}$ & Sedang & $\begin{array}{c}\mathrm{R}-03, \\
\mathrm{R}-04\end{array}$ \\
\hline & & Rendah & R-05 & Rendah & $R-06$ \\
\hline & & Tinggi & $\mathrm{R}-02$ & Tinggi & $\mathrm{R}-01$ \\
\hline & 6 & Sedang & $\mathrm{R}-03$ & Sedang & $\mathrm{R}-04$ \\
\hline & & & & Rendah & $\begin{array}{c}R-05, \\
R-06\end{array}$ \\
\hline \multirow[t]{9}{*}{$\begin{array}{c}\text { Mengeks- } \\
\text { trapolasi }\end{array}$} & 7 & - & - & Tinggi & $\begin{array}{l}\mathrm{R}-01, \\
\mathrm{R}-02\end{array}$ \\
\hline & & & & Sedang & $\begin{array}{c}\text { R-03, } \\
\text { R-04 }\end{array}$ \\
\hline & & & & Rendah & $\begin{array}{l}\text { R-05, } \\
\text { R-06 }\end{array}$ \\
\hline & 8 & & & Tinggi & $\begin{array}{l}\mathrm{R}-01, \\
\mathrm{R}-02\end{array}$ \\
\hline & & - & - & Sedang & $\begin{array}{c}\text { R-03, } \\
\text { R-04 }\end{array}$ \\
\hline & & & & Rendah & $\begin{array}{l}\text { R-05, } \\
\text { R-06 }\end{array}$ \\
\hline & 9 & & & Tinggi & $\begin{array}{l}\text { R-01, } \\
\text { R-02 }\end{array}$ \\
\hline & & - & - & Sedang & $\begin{array}{c}\mathrm{R}-03, \\
\mathrm{R}-04\end{array}$ \\
\hline & & & & Rendah & $\begin{array}{l}\text { R-05, } \\
\text { R-06 }\end{array}$ \\
\hline
\end{tabular}

1). Menerjemahkan

Berdasarkan hasil tes yang dilakukan terhadap responden pada kategori soal menerjemahkan, ditemukan bahwa sebagian kecil responden belum memahami perbedaan vektor satuan dan sumbu koordinat sehingga responden mengalami kesalahan dalam menjawab soal. Hal ini dapat dilihat dari jawaban pada soal nomor 1 yang diberikan Responden R-04, ia menuliskan vektor posisi dengan menggunakan simbol sumbu koordinat yang dinyatakan sebagai vektor satuan. Responden R-03 mengaku tidak memahami maksud dari simbol i, $j$, dan $k$ dan hubungannya dengan simbol $x, y$, dan $z$, responden hanya mengetahui bahwa dalam materi vektor simbol tersebut sering digunakan. $\mathrm{Hal}$ ini mengakibatkan responden kesulitan dalam menggambarkan vektor perpindahan. Sedangkan 4 orang responden lainnya sudah dapat memahami vektor posisi dan vektor 
satuan serta dapat menggambarkan vektor perpindahan dengan benar.

Ditemukan juga bahwa masih terdapat responden yang tidak memahami hubungan yang digambarkan posisi titik dalam koordinat polar dengan vektor posisi dalam koordinat kartesius, hal ini diungkapkan oleh responden R-06 dalam menjawab soal nomor 2 yang belum bisa memformulasikan persamaan yang menyatakan hubungan keduanya. Vektor posisi dapat diperoleh dengan menentukan nilai $x$ dan y berdasarkan gambar yang ada pada soal, yaitu dengan membuat proyeksi segitiga sikusiku serta menentukan $x$ dan y sesuai dengan rumus sinus dan cosinus. Responden R-04 mengaku sudah mengerti dan paham dengan hubungan posisi titik dalam koordinat polar dan vektor posisi dalam koordinat kartesius tetapi menuliskan persamaan yang salah yang disebabkan kurangnya ketelitian pada saat menjawab soal. Dapat dikatakan bahwa sebagian besar responden sudah mampu memahami konsep ini dengan baik.

Selain itu, Responden R-04 juga masih mengalami kebingungan dalam mendeskripsikan jarak dan perpindahan, serta masih salah dalam menentukan besaran yang termasuk vektor. Responden mengaku bahwa ia dapat membedakan jarak dan perpindahan dengan cara perhitungan, namun sulit mengungkapkan definisi dari besaran tersebut. Adapun beberapa responden yang menjawab dengan memberikan gambar akan tetapi menggunakan simbol yang tidak sesuai ilustrasi soal, namun secara umum responden sudah memahami konsep tentang jarak dan perpindahan.

\section{2). Menafsirkan}

Berdasarkan hasil tes yang dilakukan terhadap responden pada kategori soal menafsirkan, ditemukan bahwa responden R-04 menjawab soal nomor 4 untuk menentukan percepatan sesaat dengan cara menurunkan persamaan kecepatan $\left(v_{x}\right.$ dan $\left.v_{y}\right)$ terhadap waktu, kemudian membagi hasil turunan tersebut dengan waktu dalam hal ini responden menganggap waktunya adalah 2 sekon. Hal ini berbeda dengan konsep percepatan sesaat itu sendiri yang diperoleh dengan hanya mendiferensialkan kecepatan terhadap waktu, kemudian untuk memperoleh vektor percepatan pada saat 2 sekon yaitu dengan memasukkan nilai waktu tersebut ke dalam persamaan vektor percepatan sesaat. Responden R-05 juga mengalami kesalahan dalam menuliskan persamaan percepatan sesaat, responden masih bingung mengapa kecepatan memiliki komponen $x$ dan $y$, namun ia memahami bahwa cara mencari percepatan sesaat dengan cara menurunkan persamaan kecepatan tersebut. Hal ini membuktikan bahwa responden tidak memahami perbedaan percepatan sesaat dan percepatan rata-rata dan juga masih kesulitan dalam memahami makna dari persamaan yang digunakannya. Responden R-03 dan R-04 mengalami kesalahan yang sama yaitu dalam menuliskan persamaan yang digunakan untuk menjawab soal sehingga jawaban yang diberikan kurang tepat, namun kedua responden ini telah memahami bahwa untuk memperoleh vektor posisi jika diketahui vektor kecepatannya yaitu dengan menggunakan integral. Selain itu, ditemukan hampir semua responden salah dalam menyelesaikan integral, khususnya untuk responden R-01, R-03, R-04, dan R-05 masih salah dalam menjawab hasil integral 10 dt, mereka menganggap bahwa angka yang tidak mengandung variabel maka tidak diintegralkan atau hasilnya tetap.

3). Mengekstrapolasi

Berdasarkan hasil tes yang dilakukan terhadap responden pada kategori soal mengekstrapolasi, ditemukan bahwa semua responden mengalami kesalahan dalam menjawab soal. Hal ini dapat dilihat pada jawaban responden untuk soal nomor 7 , responden belum mampu menyimpulkan pernyataan yang benar berdasarkan soal yang diberikan. Responden R-02, benda dikatakan bergerak lurus berubah beraturan jika benda tersebut memiliki kecepatan yang konstan atau tetap, pernyataan ini tentu bertentangan dengan teori yang sebenarnya bahwa gerak lurus berubah beraturan terjadi jika terdapat perubahan kecepatan benda. Responden R-04 menyatakan bahwa untuk menentukan persamaan vektor kecepatan yaitu dengan mengintegralkan persamaan vektor posisi, responden belum memahami dengan baik perbedaan integral dengan diferensial. Sebagian besar responden tidak memahami cara menentukan koordinat awal, responden mengatakan bahwa hal ini disebabkan pada soal tidak dicantumkan waktu saat benda berada pada koordinat awal tersebut. Sedangkan jawaban responden untuk soal nomor 8, dapat diketahui bahwa responden tidak memahami perbedaan percepatan ratarata dengan percepatan sesaat sehingga mereka menjawab untuk menentukan vektor percepatan rata-rata yakni dengan mendiferensialkan persamaan vektor kecepatan. Seharusnya untuk menentukan vektor percepatan rat-rata yaitu dengan membagi perubahan kecepatan dengan selang waktunya. Responden R-02 menyatakan bahwa perbedaan percepatan rata-rata dan sesaat 
p-ISSN 2338-3240, e-ISSN 2580-5924

terletak pada lama waktu benda bergerak, tetapi ia masih kesulitan dalam memformulasikan persamaan keduanya. Selain itu, responden juga bingung menentukan sisi depan dan samping yang digunakan dalam mencari nilai arah karena tidak terdapat gambar, sehingga ia menuliskan persamaannya terbalik.

Selain itu juga ditemukan bahwa jawaban untuk nomor 9 yang mencakup konsep percepatan sesaat menggunakan analisis grafik v-t., responden R-02 dan R-03 menjawab soal dengan rumus percepatan rata-rata dikalikan dengan waktu, mereka menganggap bahwa waktunya adalah 2 sekon. Sementara itu, responden R-05 mengatakan bingung harus menggunakan rumus diferensial tetapi dalam soal tidak diketahui persamaannya sehingga ia memilih tidak menjawab soal, menurutnya persamaan yang digunakan untuk menentukan percepatan yaitu hanya dengan cara diferensial. Untuk responden R-01 dan R-04 menjawab hasil akhir benar namun responden menggunakan selang waktu yang sangat besar sehingga responden tersebut bukan menentukan percepatan sesaat akan tetapi percepatan rata-rata. Hal ini tidak sesuai dengan jawaban yang sebenarnya yaitu dengan cara menggambar garis singgung pada saat 2 sekon kemudian menentukan kemiringan atau sudutnya dengan persamaan tangensial. Dalam hal ini nilai percepatan saat 2 sekon yang diperoleh sama dengan besar sudut yang terbentuk.

\section{KESIMPULAN}

Berdasarkan hasil analisis tes pemahaman konsep vektor kinematika dan wawancara yang diberikan kepada 6 orang siswa kelas XII MIPA1 SMA Negeri 5 Palu, dapat disimpulkan bahwa pemahaman responden tentang vektor masih rendah. Hal ini dapat dilihat dari kemampuan responden dalam memahami konsep pada kategori berikut:

a). Menerjemahkan

Responden yang berkategori tinggi, sedang dan rendah sebagian besar sudah dapat menerjemahkan konsep vektor posisi dan vektor satuan ke dalam sistem koordinat kartesius 3 dimensi, perbedaan konsep jarak dan perpindahan serta hubungan yang digambarkan dalam bentuk grafik koordinat polar dan koordinat kartesius yang diwakili oleh soal nomor 1 , 2, dan 3 dengan baik.

b). Menafsirkan

Kategori ini diwakili oleh soal nomor 4, 5 dan 6 , hanya responden yang berkategori tinggi dan sebagian kecil siswa berkategori sedang dan rendah sudah dapat memahami dan menafsir besar vektor percepatan sesaat, vektor kecepatan dan persamaan vektor posisi dengan baik.

3). Mengekstrapolasi

Responden mengalami kesulitan terbesar dalam memahami soal kategori ini yang mencakup konsep persamaan vektor posisi, percepatan sesaat, dan percepatan rata-rata yang diwakili oleh nomor 7,8 dan 9.

\section{DAFTAR PUSTAKA}

[1] Susilo, M. Joko. (2007). Kurikulum Tingkat Satuan Pendidikan. Bandung: Alfabeta .

[2] Lubis, I. L. (2009). "Tingkatan Pemahaman Mahasiswa pada Konsep Fisika". Media Infotama. 4,(8), 14-22.

[3] Affandi, Yedi. (2014). Remediasi Kesalahan Belajar Siswa tentang Vektor dengan Pemberian Booklet disertai Umpan Balik Kelas $X$. Artikel Penelitian Program Studi Pendidikan Fisika Fkip Untan Pontianak.

[4] Handika, Jeffry \& Kurniadi, Erawan. (2014). "Analisis Kesulitan Mahasiswa dalam Memahami Konsep Vektor Gaya pada Hukum Newton". Jurnal LPPM. 2, (1), 5051.

[5] Barniol, Pablo \& Zavala, Genaro. (2010). "Vector Addition: Effect of the Context and Position of the Vectors". PhysRevSTPER. 10, (010121), 1-13.

[6] Barniol, Pablo \& Zavala, Genaro. (2012). "Student's Understanding of the Concepts of Vector Components and Vector Products". Research Gate. 10, (3515252), 4-5.

[7] Scaife, T. M. \& Heckler, A. F. (2010). "Adding and Subtracting Vectors: The Problem with the Arrow Representation". PhysRevSTPER. 11, (010101), 16.

[8] Sudjana.(2002). Metoda Statistika. Bandung: Tarsito. 